\title{
ANDREW LANG, COMPARATIVE ANTHROPOLOGY AND THE CLASSICS IN THE AFRICAN ROMANCES OF RIDER HAGGARD
}

\author{
J L Hilton (University of KwaZulu-Natal, Durban)
}

The long-standing friendship between Andrew Lang (1844-1912) ${ }^{1}$ and Henry Rider Haggard (1856-1925) is surely one of the most intriguing literary relationships of the Victorian era. ${ }^{3}$ Lang was a pre-eminent literary critic and his support for Haggard's earliest popular romances, such as King Solomon's mines (1885) and She (1887), helped to establish them as leading models of the new genre of imperial adventure fiction. ${ }^{4}$ Lang and Haggard co-authored The world's desire $(1890)^{5}$ and the ideas of Lang, who was also a brilliant Classics scholar, can be seen in many of Haggard's works. There are some significant similarities between the two men: both were approximate contemporaries who lived through the most aggressive phase of British imperialism, both were highly successfully writers who earned their living by their pens, both wrote prolifically and fluently on a wide

1 On Andrew Lang, see Donaldson 2004:453-456, Langstaff 1978, De Cocq 1968, Gordon 1928, and, above all, Green 1946.

2 The standard biographies of Rider Haggard are Etherington 1984, and Cohen 1960, somewhat dated, but very well written, but note also the more specialised studies of Stiebel 2009, 2001, Coan 2007, 2000, 1997, Monsman 2006, Pocock 1993, Fraser 1998, Vogelsberger 1984, Higgins 1981, Lewis 1984:128-132, Ellis 1978, and Bursey 1973. I owe special thanks to the local experts on Haggard, Lindy Stiebel and Stephen Coan. I am also grateful to the members of the Classics Colloquium, UKZN, Howard College, and UNISA for comments made at earlier presentations of this article.

3 On the relationship between Lang and Haggard, see Green 1946:124-137.

4 Lang's defence of Haggard against charges of plagiarism was crucial in this regard. For this long-standing controversy, to some extent provoked by Haggard's article 'The modern novel' in Saturday Review 54 (11 November 1882) 633-634, see, for example, the articles 'King plagiarism and his court' in the Fortnightly Review, March 1890:421-428, 438-439 (by James Runciman); and the anonymous article, 'Who is "She" and where did "She" come from?', in the Pall Mall Gazette, 11 March 1887:1-2. See also the correspondence on this question under the title 'Fact and fiction' in the Pall Mall Gazette, 26 March 1887:2 by Rider Haggard, Faithful Begg, and J Balfour Paul. Lang's defence of 'a close friend' can be found in, 'Literary plagiarism' Contemporary Review (June 1887:831-840).

5 The title was, according to the preface to the romance 'dealt with' by the French literary critic Paul de St. Victor, for whom see Lacroix and Delzant 1881 and the English Classicist J A Symonds (cf. Symonds 1875a:444-456, also 1875b). The phrase was taken up by Oscar Wilde in his 'The New Helen' (Poems 1881). Rider Haggard then popularised it by making it the title of his romance. 
range of subjects, ${ }^{6}$ both were largely self-educated, both were interested in the supernatural, both had had unhappy experiences in love at first but later maintained long-lasting marriages, and both were men with powerful faculties of imagination. There are, of course, significant differences also: Lang was a gifted intellectual who had won a fellowship at Oxford, a Homeric scholar, a poet with a gift for irony and humour, and one of the earliest exponents of the new science of anthropological mythology; Haggard was less well educated and more seriousminded, he preferred action to ideas, was personally involved in the extension of British rule in Southern Africa, ${ }^{7}$ and had a close experience of African tribal life. This article sets out to investigate the relationship between these two men, and to assess the extent to which Lang's classical and anthropological thinking shaped the narratives of Haggard, especially those set in his imperialistic fantasy of the African continent.

What may have attracted Lang's interest in Haggard, in addition to the phenomenal popularity of the early romances, especially King Solomon's mines (1885), may well have been passages such as the description of the 'paean of victory' by Ignosi, the 'King of the Kukuanas' (KSM pp. 206f.), as described by a hunter Evans to the narrator in this romance, Alan Quatermain:

Ignosi bound the diadem on his brows, and then advancing placed his foot upon the broad chest of his headless foe and broke out into a chant, or rather a paean of victory, so beautiful, and yet so utterly savage, that I despair of being able to give an adequate idea of it. I once heard a scholar with a fine voice read aloud from the Greek poet Homer, and I remember that the sound of the rolling lines seemed to make my blood stand still. Ignosi's chant, uttered as it was in a language as beautiful and sonorous as the old Greek, produced exactly the same effect on me, although I was exhausted with toil and many emotions.

Haggard's African battles do not shy away from graphic descriptions of cruel death and bloodshed. The battles in King Solomon's mines, and indeed in Haggard generally, are in this regard truly Homeric in their gruesome depictions of violence

6 Bibliographies of Haggard's works can be found in Siemens 1991, Whatmore 1987. For Lang, see Green 1946, Falconer 1898.

7 At the age of nineteen, Haggard was sent to South Africa as the unpaid private secretary of the lieutenant-governor of Natal, Henry Bulwer, the nephew of Bulwer-Lytton, the author of Last days of Pompeii (1834), and A strange story (1862) - featuring a quest for the elixir of life and a fire scene presided over by a woman called Ayesha - both features of Haggard's romance She. In much the same way as young aristocratic Romans acted as legates to the proconsuls of Rome, Haggard served on Bulwer's staff and later worked as an aide for Theophilus Shepstone. 
(compare the duel between Twala and Sir Henry in King Solomon's mines pp. 204-206, for example, with the combat between Achilles and Hector in Homer Iliad 22.273-374. ${ }^{8}$

Lang is best known to Classicists as a Homeric scholar. In addition to his long and critically acclaimed original poem Helen of Troy (1882) and his highly influential translations of the Iliad (co-translated in 1882 with Walter Leaf [Books 1-9] and Ernest Myers [Books 7-24]) and the Odyssey (mostly Lang corrected by S H Butcher, 1898), Lang published three books on these poems. ${ }^{9}$ On the Homeric Question, Lang was a convinced Unitarian; in Homer and the epic (1893) he argued, through an analysis of the alleged discrepancies in the poems, that the Iliad and Odyssey were composed by a single poet. This argument was continued in Homer and his age (1906), in which the poems are shown to present a coherent worldview as a result of their composition at a single point of time after the establishment of writing in Greece (p. 310). Finally, in The world of Homer (1910) he noted that morally objectionable material, such as incest on the island of Phaeacia (Od. 7), had not been expurgated from the poems and that the epics were therefore not redactions but original compositions that had survived in their entirety..$^{10}$ Interestingly, his argument in this last book largely depended on his discovery, through the application of a comparative anthropological methodology, of what he termed 'primitive' elements in Greek religion. Thus, for example, he noted distinct similarities between Greek hero cults and Zulu ancestor worship (pp. 275, 329).

Lang's Classical knowledge of Homer, and Greek literature generally, is most apparent in his co-authorship with Haggard of the historical fiction, The world's desire (1890). Lang recommended that this romance should follow the plot of Euripides' play Helen in which the Spartan queen spent the course of the Trojan War in Egypt and not in Troy as in Homer. ${ }^{11}$ Following this line of narrative would no doubt have appealed to Haggard, who had a life-long interest in Egyptology. ${ }^{12}$

8 See also, for example, Siemens 1991:8-9. Haggard was also interested in Norse legends and some of his battle scenes describe the blood lust of Viking 'beserkers' and scenes of slaughter such as recounted by Livy of the battle of Cannae (22.44-50). See Monsman 2006:123.

9 Lang 1893, 1906, 1910. On Lang's translations of Homer, see Langstaff 1978:58-60.

10 On Lang's response to Wolf's Prolegomena to the Iliad (1795) see Langstaff 1978:62-72.

11 See the letter of Lang to Haggard quoted in Haggard's autobiography, Days of my life (1926) 1.280 .

12 This abiding interest of Haggard was wholly in keeping with the mania for things Egyptian in Europe at the time. He toured the land of the pharaohs more than once, and had personal relationships with well-known personalities in the field such as Flinders Petrie, Wallis-Budge, and Howard Carter. See Addy 1998. 
The plot focuses on the jealousy that the Egyptian queen Meriamun feels for Helen over the love of Odysseus. This central motif is complicated by two sub-plots the Exodus of the Jews from Egypt under the leadership of Moses and an invasion of the country by the Achaeans. Helen is a depicted as a polyvalent character. As in Euripides' depiction of her, ${ }^{13}$ she is at once the most beautiful woman in the world, a goddess, and the cause of destruction to men. Her moral ambiguity is reflected in the central symbol of the work, the jewel that she wears - a ruby or blood-stone (haematite) that sheds blood. Such stones attracted much folklore, which was Lang's special area of expertise. ${ }^{14}$ Lang and Haggard point out in the preface to the work that Servius comments on a bloodstone at Troy in his commentary on the Aeneid 2.33 (the reference is attributed by the authors to the Vergilian scholar Mackail). Servius writes:

In this citadel [i.e. of Troy] there is said to have been a stone of this kind, which sheds blood when rubbed by another. For [they say] that Helen had often made use of a fragment of this stone to attract lovers to herself.

in hac enim arce huiusmodi saxum fuisse dicitur, quod ab alio contritum sanguinem emitteret, namque Helenam ad incitandos in se amatores saepe ex hoc saxo lapillum uti fuisse solitam.

This is not the way the stone is represented in the romance, however. Instead it is referred to as the two-fold 'Star of Love', which itself drips blood, but also becomes the 'Star of War' that sheds the blood of men. This ambiguity in the character of Helen is shown also in Victorian paintings of the Greek heroine. Whereas eighteenth-century depictions of Helen such as Jacques Louis David (1788) or François-André Vincent (1789) focus on her great beauty (in accordance with the Greek tradition, represented by the red-figure vase in the Louvre [G424]), the Victorians reveal her baneful aspect - Rosetti (1863), for example, shows her fingering a piece of jewellery in the form of a blazing brand, and Poynter (1881) has her laying hand to heart in a gesture of remorse, while in the background Troy burns. Such representations reflect Helen's complex character as it is depicted already in Greek literature, but the strong emphasis on Helen's destructive side is also a feature of Haggard's central female figures such as Ayesha in She.

Haggard often deploys material from ancient history relatively independently of Lang. This is most obvious in his fictional romance Cleopatra

13 See Symonds 1875a:450-452.

14 De Cocq 1968:80 regards Lang's insistence that literary mythology rested on a foundation of folklore and that folklore was not the detritus of higher mythology as his most significant contributions to anthropology. 
(1889) ${ }_{15}^{15}$ which, in accordance with Haggard's proclivities, adopts a strongly pro-Egyptian slant. In his narrative, Haggard focuses on the struggle of Harmachis, the son of Amenemhat, the hereditary priest and ruler of Abouthis, to re-establish the rule of the Egyptian pharaohs and to rid his land of the hated Macedonian rulers. Harmachis is portrayed as the rightful ruler of the land of Khem, since he was the linear descendant of the old pharaohs who had been defeated by the Persians and Greeks. His mother prophesied at his birth that he would rule as pharaoh if he did not fall into sin (an anachronistically Christian idea). Using magical powers, Harmachis manages to win the trust of Cleopatra and he is given the post of astrologer in her court. However, his plot to assassinate the queen fails because of the intervention of Charmian, who had become jealous of his close relationship with Cleopatra. Cleopatra secures possession of the treasures of the Ptolemies and makes use of them to wage war on Octavian. Angered by this, Harmachis eventually achieves his goal by poisoning both Antony and Cleopatra. However, his coup is too late and the Romans successfully take control of the land of the pharaohs. Harmachis confesses his failures to the Egyptian priests at Abouthis and is eventually executed in prison after writing his memoirs, which constitute the romance itself. In addition to the overt use of material from Roman and Egyptian history and culture, Cleopatra is of interest for its sympathetic treatment of the victims of imperial aggression. ${ }^{16}$ The disjuncture between Haggard's stance here and his enthusiastic support for Britain's annexation of the Transvaal in 1877 during his years as an aide to Theophilus Shepstone (he was said to have personally raised the Union Jack over Johannesburg) is sufficient indication of the political and intellectual naivety that detracts so severely from his otherwise impressive achievements. ${ }^{17}$

Throughout his life, Haggard retained interests both in contemporary politics and the Classical past and these twin interests at times coalesce in surprising ways. In 1888 he published, at his own expense, his reflections on his political experiences in South Africa, Cetywayo and his white neighbours. While Haggard undoubtedly reveals many of the prejudices of his class and time in this

15 Translated into Afrikaans by Johan Viljoen 1955.

16 For the treatment of imperialism in Haggard, see Monsman 2006, Chrisman 2000, Low 1996, McClure 1994, Katz 1987.

17 Haggard's lack of critical acumen (for which see also Lewis [1982:129-130] may be attributed to his relatively deficient education. Despite his elite social background (he was the sixth son and eighth child of William Rider Haggard, a minor member of the landed British aristocracy) Haggard did not go to university. Unlike his brothers, he was also not given a public school education (Haggard 1951:30), but was educated at home and briefly at Ipswich Grammar School. Haggard was nevertheless evidently quite familiar with the Classics and Ancient History, which were the staples of Victorian education. 
work (see, for example, p. xliii), he nevertheless frequently puts forward liberal assessments of the predicament of the Black tribes of South Africa (pp. liii, and esp. 270-288). This is particularly clear in his discussion of polygamy in Black culture and the impossibility of eradicating this custom - a view which closely reflects the difficulties confronting Bishop Colenso, whom Haggard had met, and Henry Callaway in this regard (pp. 60-63) ${ }^{18}$ Haggard's liberal sentiments were, of course, not unrelated to the struggle between Boer and Briton over political control of the land, but he also clearly responded to what he perceived as the heroic, dare I say Homeric, nobility in the character of the Zulu leaders he encountered from time to time.

Haggard's thoughts on the political situation in Natal were shaped largely by his understanding of the rise to power of Shaka (c. 1787-1828), but he made sense of these events by relating them to a world more familiar to him - that of ancient Rome. In Nada the Lily (1892), a historical novel set during the reign of Shaka, Haggard explores the dynamics of life in a polygamous society. In this novel, the hero, Umslopogaas, is in love with the beautiful Nada, who is the granddaughter of a Portuguese trader / explorer. However, he is inevitably embroiled in the power struggles among the various families in Shaka's kraal and is driven out into the wilds. There he joins the wolf-man, Galazi, and together they live as outlaws, carrying out heroic exploits to win renown. For example, Galazi wins the prize of his fabulous club, named Watcher, by reclaiming from the wolves' cave a shrivelled corpse, while Umslopogaas won the axe, called Slaughterer, by killing an enemy leader. These details of the narrative are drawn simultaneously from Zulu custom and Classical culture. The Zulu are known to have given such names to their clubs, ${ }^{19}$ but at the same time there are no wolves in Zululand, and the outcast lifestyles of Umslopogaas and Galazi are clearly modelled on the legend of Romulus and Remus. ${ }^{20}$

18 Haggard 1926:1.56; Monsman 2006:122. Canon Henry Callaway's thoughts on polygamy and Christianity are preserved in Callaway 1862. Callaway 1870 frequently compares Zulu beliefs with their classical counterparts. Thus, Ukulunkulu is compared with Prometheus in being both man and creator (1870:43), while the jealousy of the gods is found in both cultures also (1870:175).

19 Callaway 1870:165-168, esp. 166 and n. 26.

20 Monsman 2006:121-128. Monsman 2006:168-169 also notes the similarity between Haggard's Child of storm (1913) - ostensibly a description of the Zulu war of succession - and the Iliad. Mameena, Haggard states in his preface (p. ix) is the 'Zulu Helen', Menelaus is Saduko in the novel. Mameena-Helen is seduced by Paris who is Umbelazi, son of Panda. Like Helen, Mameena has close relationship with moongoddess as Aphrodite in the romance. Haggard simplifies somewhat by conflating Paris with Hector, the handsome, most loved warrior, and Menelaus with Achilles, whose proud anger and withdrawal from battle models that of Saduko's. As Hector is killed by 
The presence of Zulu founding twins in the Drakensberg points to another area in which Lang's ideas were at work in Haggard's oeuvre - comparative anthropology. ${ }^{21}$ E B Tylor had published his Primitive culture: Researches into the development of mythology, philosophy, religion, art and custom in 1871. Lang's Custom and myth appeared in 1884, while his two volume study Myth, ritual and religion dates to 1887 . James Frazer's Golden bough appeared in two volumes in $1890 .^{22}$ However, Lang also developed his theory of mythology under the inspiration of comparative philology, first formulated by William Jones in the 1780's. ${ }^{23}$ Lang writes:

The critical nineteenth century brought in . . . a closer analysis (sc. of myth); and finally, in the sudden rise of comparative philology, it chanced that philologists annexed the domain of myths. Each of these systems had its own amount of truth, but each certainly failed to unravel the whole web of tradition and of foolish faith (Lang 1887:1.30).

In Lang's view Classical myths of metamorphosis are reflected in the beliefs of those he described as 'primitive' people. His aim was to explain the irrational elements in the myths of 'civilised peoples' as a survival from a period of 'savagery'. Thus he reports that the Hottentots (his term) believed that the stars were transformed and transfigured men, just as the Greeks did. His ideas were bolstered by current theories of evolution, which explained why mythology grew and developed in a series of modifications. All cultures, he believed, pass through a series of stages of development - phylogeny replicates ontogeny. In this way barbaric myths were purified or explained away by more advanced civilisations. He argued that his theory of mythology was 'only an application to this particular province, mythology, of the method by which the development either of organisms or of human institutions is traced. ${ }^{24}$ This system explained why similar myths are encountered in places far removed from one another geographically, chronologically, and culturally. In order to test his thesis, Lang needed to investigate

Achilles, so Saduko's outright treason against Umbelazi destroys that prince. In this shadow play, Allan Quatermain is, of course, the crafty resourceful Ulysses.

21 For Lang's place in the history of anthropology, see De Cocq 1968; Lang 1908:44-65. Lang talks of 'the fossiliferous strata of myth', p. 45, indicating his awareness of evolutionary theory. Lang's work on totemism has been published posthumously by Duff-Cooper 1995. For Haggard's interest in Lang's anthropological work, see Fraser 1998:30.

$22 \quad$ Vickery 1973.

23 For Jones' well-known theory that Sanskrit, Greek, Latin, English and other languages belong to the Indo-European family of languages, see Cannon 1979.

24 See Lang 1887:1.29-47 (the quote is on p. 40). The beliefs of the San were recorded by Bleek and Lloyd 1919, and have recently been reinterpreted by Wessels 2010. 
folklore and folktales from across the world. It was this that drew his attention to Haggard's use of Zulu material in his romances and the records of Zulu myths preserved by Callaway (1868a, 1868b, 1870). Lang, who was an atheist, considered the Zulu 'the finest, and certainly among the least religious, of the undeveloped peoples' whose faith is mostly in magic and ghosts but with 'traces of a loftier belief' ${ }^{25}$ Thus he notes in Myth, ritual and religion that the Zulu do not kill certain snakes believing them to be the spirits of their ancestors, just as the snake that appeared when Aeneas was sacrificing was thought to be the ghost of Anchises (Vergil Aen. 5.72-103); the Zulus do not mourn cattle killed by lightning in the same way as the Romans did not bury people who died in this way; ${ }^{26}$ the Zulu think that the spirits speak though whistling, just as in Homer (Od. 24.5) the souls of the dead resemble the squeaking of bats (this motif is used in Haggard's Cleopatra); rain-makers among the Zulu are 'heaven-herds' like Zeus the 'cloud-gatherer' or the Homeric kings who exercise influence over the physical universe, ${ }^{27}$ the Zulus and Greeks, like many other peoples, shared the belief that heaven is a solid roof over the world $;^{28}$ and in Zulu belief the first man was regurgitated like the son of Cronus in the Greek version. Lang makes use of the Zulu belief in Ukulunkulu = 'The Old, Old One' to substantiate his theory that humans had originally believed in a single supreme deity before developing polytheistic beliefs. ${ }^{29}$

Lang compares the Greek cult of Demeter with Zulu parallels (1887:2.284). There is a cult of a rain-goddess, or rain-queen, among the Zulu, Nomkhubulwane, whose white colour may reflect the white clay with which her face was smeared during rituals. ${ }^{30}$ Haggard's fictional romance The ghost kings (1908) tells of a white girl who won great power among the Zulu. In the preface to the work (pp. 16-17) Haggard explains that there was a legend concerning the daughter of a white missionary whose parents were murdered by Dingaan and who cursed him for this action. As a result misfortune came upon the Zulu at this time. To get rid of the girl and her curse the Zulu are said to have sold the girl to dwarf people who lived in

25 Lang probably obtained his information on the alleged atheism of the Zulus and African tribes in general from Callaway 1870:29-30, 107-108.

26 Callaway 1870:118.

27 Callaway 1870:375-393: in Zulu belief, as in Greek, thunder and lightning is associated with birds (ibid. p. 381-382).

28 Callaway 1870:393-394.

29 Argued in Lang 1897, but see also Callaway $1868=1870: 1-104$.

30 See Lambert, esp. 2008:545-553, but also 2009:19-35, 1990:46-59; Krige 1943:271-281. Lambert 2011:84-86 rejects Bryant's diffusionist theory (1949:676) that the Zulu Nomkhubulwane is a direct borrowing from the Greek Demeter / Persephone, and suggests (p. 90) that his own discussion of the mother goddess cult may have influenced subsequent Zulu rituals. 
the forest and worshipped trees. However, the curse remained and afflicted the Zulu nation. Are these legends and beliefs the background to Haggard's fictional romances or was he influenced instead by Greek romances such as Heliodoros' Aethiopica with its white princess, the daughter of the black king and queen of Ethiopia, or indeed by his persistent belief that Phoenicians penetrated deep into Africa and set up kingdoms there $?^{31}$

Lang also notes other coincidences between Zulu and Greek belief: that in ancient Greece a priest covered his face with a mask of Demeter and then beat the earth with rods calling on the spirits in the underworld in the same way as a Zulu sangoma, when in a state of divination, commands the people to strike the earth to summon the spirits. Elsewhere he notes that in both Africa and Greece members of a cult daubed their faces with clay $(1855: 33,39$, cf. Demosthenes On the crown 259.4, while Hdt. 8.27 mentions that white clay was smeared on the faces of warriors to intimidate their enemies). The Cape Bushmen dance out their mysteries just as the Greeks did (Lucian On dancing 15, cf. Lang 1885:41). Lang observes (ibid.) that 'there are thus undeniably close resemblances between the Greek mysteries and those of the lowest contemporary races'. Such comparative studies of mythology provided Haggard with a universal female goddess whose presence can be felt in many of his female characters.

One of Lang's most sustained demonstrations of the relationship between the Classical and Zulu religious beliefs concern the story of Cupid and Psyche in Apuleius and the tale of Umtombinde (Lang 1885:64-86; 1887:xvii-lxxxvi). ${ }^{32}$ Lang refers to the observations of Emmanuel Cosquin (p. xix), who noted in 1886 connections between Apuleius' tale and Indian stories in his Contes de Lorraine. He stresses also that his purpose is only to point out essential elements in the versions cited (p. xxv) before relating the narrative of Umtombinde ('the tall maiden'). ${ }^{33}$ The story begins with the girl's resolution to go to a dangerous place beside the mythical river Ilulunge where she is to be married to her lover, but no bridegroom appears. The intended youth, Unthlatu, the youngest prince, had disappeared as a child. The girl stays there, and meat and beer are placed in her hut, but these are nightly devoured by an invisible being, who is in fact the

31 For the racial identity of Charikleia in the Aethiopica, see Hilton 1998:79-92; on her presence in Haggard's fiction, see Vinson 2008:289-315. Haggard does not always reveal the sources of his inspiration, of course, but Heliodorus' Aethiopica was familiar to Victorian readers from Underdowne's 1587 translation reissued in 1895. The novel had also been translated into English by Smith in 1855. Haggard's white queens are often explicitly described as Phoenician (cf., e.g., the plot of Elissa provided below).

32 Further connections between Apuleius's narrative and folktales are provided by Boberg 1938; Schlam 1993. The story was a great favourite of the Victorians, see Morris 1872, Bridges 1898 as well as early twentieth-century English scholars (Pater 1934).

33 Lang 1887:1xxviii-lxxx. 
mysterious prince. One night he comes in the dark and feels the girl's face. In the morning he goes away, without being seen. During all these days he will not allow the girl to light a fire. Next night Unthlatu makes the girl feel his body, which is as slippery as a snake. She lights a fire and sees that her 'husband' had a shining body. The strange bridegroom says that he had disappeared as a child because his elder brothers were jealous of, and threatened to strangle him, because he would become king. Eventually Unthlatu is restored to his position as king after being released from his serpent form by Untombinde's love. This story shows obvious similarities to Apuleius' tale of Cupid and Psyche. ${ }^{34}$ Lang further argues that Cupid's command that Psyche should not seek to see him is similar to the Zulu custom of hlonipha in which a wife is forbidden to use the syllables of her husband's name (1887:xlv). ${ }^{35}$ Lang adduces further similarities, such as the Zulu belief that men can take the form of animals while retaining their human faculties.

Comparative mythological analyses of this kind were undoubtedly in circulation in Haggard's day and these, together with his own experiences of African tribal life, would have shaped some of his most memorable characters, especially Ayesha in She (1887), about whom much has been written, most notably an extended analysis of her as the Jungian anima, and an analysis of the sexual insecurities of Victorian gentlemen such as Lang and Haggard displayed in episodes of this kind. ${ }^{36}$ Ayesha in She resembles an amalgam of female mythological characters in Graeco-Roman epic and romance. She is also a Circe, a Medusa, and Demeter in one. ${ }^{37}$

The rather unusual and much-parodied title of this romance, derives, I would suggest, partly from his mother's name, Ella, which resembles the French Elle, or She, ${ }^{38}$ partly from the description of Isis in Book 11.4 of Apuleius'

34 Lang argues that it was unlikely that the Zulus had heard this tale from the white settlers in their kingdom (p. xxvii) because the Zulu do not readily receive new stories (as noted by Callaway 1868a:2). See also generally Callaway 1868b; 1870; 1879; Bryant 1949.

35 The custom of hlonipha had also been noted by Max Müller 1867:2.216; 1861:2.39; Callaway 1870:316.

36 For the Jungian analysis, cf. Brunner (trans. Heuscher, ed. May 1986:3-121; the analysis draws frequently on ancient religious ideas: cf., e.g., p. 118 'What is intended is a hieros gamos between She and Leo', an ancient, solemn rite performed as a mystery in the temple between priestess and priest, the representatives of the godhead'. The sexual insecurities are probed by Showalter 1999. For critical assessments of Haggard's work, especially its 'mythopoeic' qualities, see C S Lewis 1984:128-132, esp. 130: 'Haggard is the text-book case of the mythopoeic gift pure and simple'; Atwood 1982:35-54; Graham Greene 1969: 209-214, esp. 209: 'perhaps the greatest of all who enchanted us when we were young'.

37 Monsman 2006:90, 194-195.

38 Ella Doveton Haggard, herself the author of an orientalising epic poem in nine cantos called Myra, or the Rose of the East. A tale of the Afghan war in nine cantos (1857). 
Metamorphoses as translated into Elizabethan English by William Adlington. This version first appeared in 1566 but it had long been used as the standard version of the novel because of its quaint English, which serves as an analogue to Apuleius' Africitas. Adlington translates En adsum tuis commota, Luci, precibus, rerum naturae parens as 'Behold Lucius I am come, thy weeping and prayers hath mooved mee to succour thee. I am she that is the naturall mother of all things'. Apuleius in turn recalls the Invocation to Venus in the prologue to Lucretius' $D e$ Rerum Natura. Adlington's translation is not among the sale brochure of books from Haggard's library, ${ }^{39}$ although the Cupid and Psyche tale does feature there. ${ }^{40}$ However Lucretius's poem is, in Latin, and Haggard's Latin may well have been up to reading the Invocation to Venus in the original. ${ }^{41}$

Given the powerful portrayal of Ayesha in the romance, it is worthwhile asking to what extent the description of the ancient Egyptian queen (p. 156) resembles Apuleius' Isis or Lucretius' Venus. Ayesha is certainly an unusual woman: she speaks Arabic, but is apparently immortal, she is served by deaf-mute maids, whom she had deliberately bred over many centuries with this disability so that they would not divulge her secrets. ${ }^{42}$ Previously, her attempts to produce this race of beings had proved to be ugly and so they were allowed to die out. She also bred a race of giants but Nature 'sickened of it and it withered away' (p. 154). These allusions, especially the reference to Titans, recall Greek creation myths, but they may also owe something to the procreative power of Lucretius' Venus, and contemporary ideas of human evolution. However, Ayesha warns Holly not to ask to look on her face, reminding him of the fate of Actaeon in Greek mythology, and describing herself as Artemis / Diana ('I too, O Holly, am a virgin goddess, not to be moved of any man, save one, and it is not thou', p. 157), although Holly notes that she had 'an air of sublime coquetry that would have been worthy of Venus Victrix' - an explicit reference to the Venus tableau in the Metamorphoses which tells the story of the beauty contest judged by Paris in which Venus won the prize.

39 However, Adlington's translation was so well known that it is unlikely that Haggard would not have known of it.

40 This is apparent from the auction list of Haggard's library, kindly supplied to me by Stephen Coan.

41 Haggard writes in his autobiography (1926:1.203f.) of an examination for admission to the bar that he took on his return from South Africa: 'My Latin I had practically forgotten ... So, I set to work and, with the assistance of a crammer, in a month learned more Latin than I had done all the time I was at school; indeed at the end of a few weeks I could read Caesar fluently and Virgil not so ill'.

42 Haggard's powerful female rulers may derive in part from his anthropological interest in matrilinear succession. Cf. Fraser 1998:42-43. For the notion of reincarnation in Haggard see the discussion in Fraser 1998:44-45. On Ayesha see particularly Miller 1952:81-100. 
Like Lucius in Apuleius' Metamorphoses, who is also warned off sexual encounters by an allusion to the myth of Actaeon, Holly's curiosity gets the better of him and he insists on looking on Ayesha's fatal beauty.

In his description, Haggard refers obliquely to the queen's arms and hair before moving on to describe her diaphanous dress, her gold-studded sandals, and a belt that consisted of a double-headed snake of solid gold 'above which her gracious form swelled up in lines as pure as they were lovely, till the kirtle ended at the snowy argent of her breast' (p. 156). Her beauty, however, does not reside in her physical features but in 'a visible majesty, an imperial grace, in a godlike stamp of softened power, which shone upon that radiant countenance like a living halo.' Further small details recall Apuleius' description of Venus in the 'Judgement of Paris' tableau, and the epiphany of Isis in Book 11. In his account of Isis, Apuleius makes much of the goddess's hair, and the 'rearing snakes' that entwine themselves around her crown. Her 'ambrosial feet ... were shod in sandals woven from leaves of victory-palm' (11.4). She exhales the fertile fragrances of Arabia, and bears herself with divine majesty. In the 'Judgement of Paris' tableau, Venus appears as a young virgin with a perfect figure, naked except for a piece of sheer silk that wafted in the breeze, emphasising the voluptuousness of her body (10.31). At the same time Ayesha is a cruel tyrant of murderous propensities, who had murdered Kallikrates in a fit of jealous rage, much as Apuleius' women behave when thwarted of their desires. A few examples will suffice: a lustful stepmother (10.2-3); a Corinthian lady overcome by an insane passion for the eponymous ass (10.19-22); and a female criminal condemned to be executed in the arena $(10.24-25) .^{43}$

However, She resembles Heliodorus' Charikleia as well. Vinson argues that Kallikrates is no other than Heliodorus' Kalasiris, ${ }^{44}$ both works feature a mysterious written communication from a female progenitor that leads them to seek their real identity, and there is an oath of chastity in both romances. More importantly, in Heliodorus (3.4) Charikleia wears a breastband of gold consisting of two snakes whose tails intertwine at the back and whose necks encircle her breasts in an intricate knot. The serpents appear to move without cruelty but with a sensuous languour as if lulled by the 'sweet joys' of her bosom. Ayesha has a mark on her arm as Charikleia does, though the Arab queen's is a scar acquired when she was stoned by the Jews, whereas Charikleia has a pure black birthmark on her gleaming white arm. Both are significant marks of identification. In addition, the Pillar of Fire in which Ayesha had first gained her immortality resembles the flames by which Charikleia is surrounded but by which she is miraculously not

\footnotetext{
43 Hilton 2009:84-105, at 101.

44 Vinson 2008:289-315 at 299.
} 
harmed when the lecherous Persian Queen, Arsake, attempts to have her burnt at the stake for witchcraft. This miracle, which owes much to tales of female martyrdom in late antiquity, is due to the fact that the heroine wears a magical pantarb stone - a gift from her mother - that protects her in the blaze. A similar ring features in She as the one worn by Kallikrates and handed down by him to his Victorian English avatar. The evil side of Ayesha finds a counterpart in Heliodorus's wicked queen Arsake in respect of her evil concupiscence. There are resemblances, therefore, between Haggard's lead character and those in the ancient romances, but differences too abound: Apuleius and Heliodorus are far more explicit about the sexuality of these females than Haggard, who emphasises Ayesha's 'grief and passion' and the 'shadow of sin and sorrow' in her face. Ayesha has done evil and will continue to do so until she is redeemed. Apuleius and Heliodorus have been Christianised.

A final theme in Haggard that has Classical antecedents involves a mythical, lost civilisation. ${ }^{45}$ Haggard's first popular success, King Solomon's Mines (1885), tells the story of how the explorer Allan Quatermain leads an expedition into Africa to find his friend's lost brother. He succeeds and brings back to England the rich treasure derived from the mines of the Biblical monarch. ${ }^{46}$ The legend of these mines is told by a hunter, Evans, who later dies, to the narrator Quatermain, as follows (pp. 14f.):

... he went on to tell me how he had found in the far interior a ruined city, which he believed to be the Ophir of the Bible - and by the way, other more learned men have said the same long since poor Evans' time. I was, I remember, listening open-eared to all these wonders, for I was young at the time, and this story of an ancient civilisation, and of the treasure which those old Jewish or Phoenician adventurers used to extract from a country long since lapsed into the darkest barbarism, took a great hold upon my imagination ...

In this passage, as often elsewhere, Haggard seems to be writing almost autobiographically. He refers to archaeological theories of 'more learned men' concerning a vaguely determined Semitic civilisation which had succumbed to the savagery of Africa - certainly the famous Zimbabwe ruins, Great Zimbabwe, Mapungubwe, or Monomotapa. Haggard was familiar with the debate around the construction of these ruins. He visited this site and wrote a preface to Wilmot's

45 Compare Bulwer-Lytton's novel The coming race (1871) which featured long-lived people who have great scientific expertise. These details are also present in Haggard's When the world shook (1918).

46 Cf. 1 Kings 26-28. 
pioneering study (1896). ${ }^{47} \mathrm{He}$ describes one of his romances, Elissa, as 'an attempt, difficult enough owing to the scantiness of the material left to us by time, to recreate the life of the ancient Phoenician Zimbabwe, whose ruins still stand in Rhodesia. ${ }^{48}$ In his preface to Elissa he speculates on the origins and the 'decline and fall' of this civilisation as if it were the mighty Roman Empire, as follows:

... there remains ample room for speculation both as to the dim beginnings of the ancient city and its still dimmer end, whereof we can guess only, when it became weakened by luxury and the mixture of races, that hordes of invading savages stamped it out of existence beneath their blood-stained feet, as, in after ages, they stamped out the Empire of Monomotapa.

The references to 'luxury', 'mixture of races', and 'hordes of invading savages' none of which are remotely applicable to the historical situation of Mapungubwe - clearly recall Gibbon's The history of the decline and fall of the Roman Empire, some of whose ideas Haggard here transfers implausibly to Southern Africa. The story of Elissa: The doom of Zimbabwe (1899) concerns the love of Prince Aziel, a Hebrew, for Elissa, the priestess of Baaltis and the daughter of the governor of Zimboe, which is being attacked by Ithobal, a tyrant of mixed race, who seeks Elissa's hand in marriage. The romance concludes with the suicide of the heroine. The narrative clearly follows the main lines of the Dido and Aeneas story in Vergil's Aeneid $($ Aziel $=$ Aeneas, Elissa $=$ Dido, Ithobal $=$ Iarbas, and so on $)$.

One of the better-educated characters in King Solomon's mines (1885), Sir Henry Curtis, 'who had taken a high degree in classics at college' (p. 226), was of the view (p. 92, cf. also p. 231) that their fictional ruins were Egyptian and thus even earlier than King Solomon, whose reign is conventionally dated to the beginning of the first millennium BC. The author himself notes the stalactites in the treasure cave had been carved into the form of 'one of the Egyptian gods' (p. 229) three thousand years earlier. Three colossal seated statues, two male, one female are "Ashtoreth, the goddess of the Zidonians, Chemoah the god of the Moabites, and Milcom the god of the children of Ammon' (p. 226). ${ }^{49}$ Sir Henry interprets the Biblical Ashtoreth as Astarte, who is the same as 'Aphrodite of the Greeks', with horns like the half-moon, and suggests that the figures were made by Phoenicians. However, Haggard is as ready to see Greek art as he is Phoenician or

47 Lang followed this debate with interest, going so far as to compose a poem on the Zimbabwe Ruins (Days of my life, 1.243). For Haggard's knowledge of the ruins, see Etherington 1977:436-438.

48 Works published in Rider Haggard's day, were: Bent 1892, 1893, Wilmot 1896, Hall \& Neal 1902. The Phoenician theory is later contradicted by Caton-Thompson 1931, Cf. Tangri 1990:293-304, Rosie 1937. See now also Tiley 2004, Huffman 1987, 2008.

49 For the names, see 1 Kings 11.5, 11.33; 2 Kings 23.11. 
Egyptian sculpture in his African material. He describes the form of a Zulu warrior (p. 95), who had just thrown a spear, thus: 'In front of them stood a youth of about seventeen, his hand still raised and his body bent forward in the attitude of a Grecian statue of a spear-thrower'. There are many other Classical allusions: fictional 'Kukuana' warriors defend a pass 'as the three Romans once held the bridge against thousands' (p. 191); a Black African girl is said to be 'nervously picking a flower from her wreath to pieces, petal by petal' before being sacrificed to the gods (p. 156); the massed ranks of the Black African warriors are a potential gladiatorial show 'arranged regardless of expense' (p. 138); and the executions that followed the 'sniffing out' by the witch-doctor, Gagool (p. 143) are said to be far worse than the bloodshed of the Roman arena:

And so the deadly game went on, till some hundred bodies were stretched in rows behind us. I have heard of the gladiatorial shows of the Caesars, and of the Spanish bull-fights, but I take the liberty of doubting if they were either of them half as horrible as this Kukuana witchhunt. Gladiatorial shows and Spanish bull-fights, at any rate, contributed to the public amusement, which certainly was not the case here. The most confirmed sensation-monger would fight shy of sensation if he knew that it was well on the cards that he would, in his own proper person, be the subject of the next "event".

The defensive attitude here is revealing. Many modern studies of the games that took place in Roman amphitheatres show that they often involved considerable bloodshed. ${ }^{50}$

Classical references of this kind occur with great regularity throughout Haggard's best-selling fiction. The apogee of this occurs in what is today probably his most highly rated thriller, She (1887). ${ }^{51}$ In the third chapter, the reader is confronted with facsimiles of the 'Sherd of Amenartas' - fragments of an ancient vase inscribed in Classical Greek (in both unpunctuated upper case and punctuated and accented cursive script), Latin (both abbreviated Black-Letter Medieval Latin and a fully expanded Classical Latin version), and English (Old English and Haggard's usual formal nineteenth century pseudo-archaic language replete with 'thee's and 'thou's). Such elaboration was necessary, since Haggard's readership consisted of men such as Mr. John Bird, who could repeat any book of Homer without making five mistakes (The days of my life, 1.68), and the Rev. Robert Sanderson, who reputedly knew the first six books of the Iliad by heart and could recite at will starting from whatever line was given him. Haggard did not compose

50 See, for example, most recently Kohne 2000, Kyle 1998.

51 This romance has frequently been reprinted and republished, most recently in annotated editions by Etherington 1991, Atwood 2002, and Staffer 2006. 
these texts himself but requested the help of his old headmaster, Dr. H A Holden (The days of my life 1.252) for the Greek and the Rev. Dr. John James Raven for the Latin and medieval English (ibid.). Such authenticating devices are a wellknown feature of both ancient and modern romances. In this case, however, there is more to this - Haggard insists on the direct connection between the ancient world and Victorian England. He notes rather sceptically in his autobiography (1.254) that a friend had informed him that his (i.e. Haggard's) previous incarnations were that of a noble at the time of Pepi II, one of the minor pharaohs, and a Norseman of the $7^{\text {th }}$ century who was one of the first to sail on the Nile.

The terrain in which the action of She takes place features a volcanic mountain and man-made canals made by a great race that carved pictures on the walls of their city and who died of a pestilence (p. 148). This becomes apparent from details eked out in the course of the narrative, as follows:

... those who were before us, by wonderful arts of which I know nought, hewed a path for the water through the solid rock of the mountain, piercing even to the bed of the lake ... (p. 129).

... the people whereof I speak built a might city, whereof nought but ruins and the name of Kôr remaineth ... (p. 130)

Although Haggard takes care not to invoke Atlantis directly (his narrator comments that the artwork he saw was 'not Greek, Egyptian or Hebrew nor Assyrian more Chinese than anything else ...' (p. 134), there is no doubt that his model was Plato's mythical city. ${ }^{52}$ In the course of a guided tour through her cavecity, Ayesha translates an inscription for Holly that describes how the civilisation of Kôr possessed navies that traded throughout the world. They had harbours in addition to canals (p. 173), but they had been overcome by a plague and famine and would rule the world no more. She comments to Holly that 'Time eats up the works of man ... the sea swallows them, or the earthquake shakes them in.' Holly admires the splendour of the city as he walks 'up the splendid streets, on past fountains, palaces, and temples such as the eye of man never saw' (p. 196). Haggard clearly has the Atlantis narrative in Plato's Timaeus and Critias in mind here - he even makes his narrator reflect how 'some antiquarian friends of my own at Cambridge' would be envious of him if he ever had a chance to describe these ruins to them (p. 139). At one point, one of his 'antiquarian friends', Andrew

52 Haggard's circumspect deployment of Plato's famous myth is the real origin of the 'Lost city' theme (as in Sol Kerzner's resort), now well analysed by Murray 1996:149-176. See also Stiebel (2001:103-130) for the influence of Haggard on later South African fiction, including John Buchan (Prester John 1910), Wilbur Smith (Sunbird 1972), and others. See also Smith 1978:149-152. 
Lang, had suggested to him 'one of the old Greek legends that ended in a most horrible all round tragedy' (The days of my life, 2.76), and many years later, in 1918, Haggard wrote an explicit account of an Atlantis, which he located in the Pacific - one of the wilder suggestions for the location for Plato's island civilisation made inter alios by the notorious theosophist, Madame Blavatsky, who located the fabled archipelago in the 'the North and South Atlantic regions, as well as portions of the North and South Pacific, and had islands even in the Indian Ocean (relics of Lemuria)'. ${ }^{33}$ Haggard shared the theosophical interests of Blavatsky, who was a well known celebrity in nineteenth century London society. When the world shook (serialised in 1918) tells the adventures of a trio of Englishmen, Bastin, Bickley and Arbuthnot, who travel to the South Sea Islands where they are wrecked by a storm on an island inhabited by backward savages, although these have some dim atavistic memories of a mysterious older world. Arbuthnot soon discovers that the bedrock of the island has been excavated by some strange technology. In the excavated rock he finds the hand of a statue 'exquisitely finished and apparently broken from a statue that might have been the work of one of the great Greek sculptors'. The adventurers discover ruins on the island that are 250,000 years old and inhabited by corpses which had been undergoing a 'deep sleep' and which they manage to resurrect. These show them an underground city with superior technology (including aeroplanes!) and supernatural spiritual powers but which had been destroyed for opposing their god, Oro. At this point Haggard provides an interesting twist to this hackneyed theme. The revived dead, an old man and his daughter, are capable of transporting themselves instantaneously across the world and travel to England to witness the political disturbances there including World War I, the Irish Question, and the rise of the suffragette movement.

In conclusion, Lang and Haggard shared an extensive knowledge and appreciation of the Classics. This was after all the bedrock on which their cultural ideas and self-perception as English gentlemen rested. Classical Greek and Roman texts, including Homer, Plato, Euripides and Vergil, and mythological themes are deployed extensively in Haggard's romances and constitute the backbone of many of his plots, though names and details are usually adapted to new contexts. The ancient romances in particular, especially Apuleius and Heliodorus, also provided him with unusual and powerful female characters. Haggard's powerful imagination created ancient kingdoms in the terrain of Africa that are reminiscent of Plato's Atlantis and the fabled civilisation of the Carthaginians. Both Haggard and Lang responded creatively to the new scientific ideas of their age that were radically

53 Blavatsky 1884:2.402-409, at 405. For a recent full account of Helena Blavatsky's extraordinarily influential life, see Cranston 1993. 
altering the conventional views of established religion. The interest of the leading figures of the new science of psychology, Freud and Jung, in the ambivalent figure of Ayesha in She, suggests that Haggard's evocative use of Classical myth in shaping his powerful female characters was a premonition of the growing strength of this field. Lang's extensive investigations of comparative mythological themes in the more general context of Darwinian theories of evolution clearly shaped Haggard's fiction, while Lang was in turn evidently intrigued by the imaginative creations and cultural adaptations in Haggard's romances. Lang's anthropological investigations and Haggard's occasional fictionalisation of them were, and still are, reminders that there is much in human nature that unites rather than divides. Their complex literary relationship certainly shaped the later development of popular fiction set in Africa and left behind a fantastic conception of the continent and its mysterious past that owes much to the influence of the ancient Mediterranean world.

\section{BIBLIOGRAPHY}

Addy, S M 1998. Rider Haggard and Egypt. London: A L Publications.

Atwood, M (ed.) 2002. Haggard, H R: She: A history of adventure. New York: The Modern Library.

Atwood, M E 1982. Superwoman drawn and quartered: The early forms of She.

In Atwood, M (ed.) 1982. Second words: Selected critical prose, 35-54. Toronto: Anansi.

Bent, J T 1892. The great Zimbabwe ruins. The Architect February 1892.

Bent, J T 1893. The ruined cities of Mashonaland being a record of excavation and exploration in 1891. London: Longman.

Berglund, A-I 1976. Zulu thought-patterns and symbolism. Cape Town: David Philip.

Blavatsky, HP 1884. The secret doctrine. London: Theosophical Publishing House. Bleek, W H I \& Lloyd, L 1919. Specimens of Bushman folklore. London: G Allen. Boberg, I M 1938. The tale of Cupid and Psyche. Classica et Mediaevalia 58:177-216.

Bridges, R 1898. Eros and Psyche: A narrative poem in twelve measures. Poetical works of Robert Bridges, 75-107. London: Smith, Elder \& Co.

Brunner, C (trans. Heuscher, J, ed. May, D S). 1986. Brunner, C: Anima as fate. Dallas, Tex.: Spring Publications.

Bryant, A T 1949. The Zulu people. Pietermaritzburg: Shuter \& Shooter. Bursey, W 1973. Rider Haggard: A study in popular fiction. PhD thesis Memorial University of Newfoundland. St. John's: Memorial University of Newfoundland. 
Callaway, H 1862. Polygamy a bar to admission into the Christian church. Durban: J O Browne.

Callaway, H 1868a. Nursery tales, traditions, and histories of the Zulus, in their own words, with a translation into English. Springvale: J A Blair.

Callaway, H 1868b. Unkulunkulu or, the tradition of creation as existing among the Amazulu and other tribes of South Africa in their own words with a translation into English and notes. Springvale: $\mathrm{J}$ A Blair = Callaway, $\mathrm{H}$ 1870, pp. 1-104. The religious system of the AmaZulu. Durban: Adams.

Callaway, H 1870. The religious system of the AmaZulu. Durban: Adams.

Callaway, H 1879. Some points of correspondence between the folk-lore of central Africa and that of Kafirs, and Chaldea. Cape Town.

Cannon, G H 1979. Sir William Jones: A bibliography of primary and secondary sources. Amsterdam: Benjamins.

Caton-Thompson, G 1931. The Zimbabwe culture : Ruins and reactions. Oxford: Clarendon Press.

Chrisman, L 2000. Rereading the imperial romance: British imperialism and South African resistance in Haggard, Schreiner, and Plaatje. Oxford: Clarendon.

Coan, S 1997. "When I was concerned with great men and great events": Sir Rider Haggard in Natal. Natalia 26:17-58.

Coan, S (ed.) 2000. H Rider Haggard: Diary of an African journey. Pietermaritzburg: University of Natal Press.

Coan, S \& Tella, A (eds.) 2007. H Rider Haggard: Mameema and other plays. Pietermaritzburg: University of Natal Press.

Cohen, M 1960. Rider Haggard: His life and works. London: Hutchinson.

Cranston, S L 1993. HPB: The extraordinary life and influence of Helena Blavatsky, founder of the Modern Theosophical Movement. New York: G P Putnam's Sons.

De Cocq, A P L 1968. Andrew Lang: A nineteenth century anthropologist. $\mathrm{PhD}$, Social Science: Rijksuniversiteit te Utrecht, Tilburg.

Donaldson, W 2004. Andrew Lang (1844-1912). In Matthew, H C G \& Harrison, B (eds.) 2004. Oxford Dictionary of National Biography, 453-456. Oxford: Oxford University Press.

Duff-Cooper, A 1995. Andrew Lang on totemism: The 1912 text of totemism. (CSAC monographs). Canterbury: The University of Kent at Canterbury.

Ellis, P B 1978. H Rider Haggard: A voice from the infinite. London: Routledge \& Kegan Paul.

Etherington, N 1977. South African origins of Rider Haggard's early African romances. Notes and Queries October: 436-438.

Etherington, N 1984. Rider Haggard. Boston: Twayne Publishers. 
Etherington, N (ed.) 1991. H Rider Haggard: The annotated She. Bloomington: Indiana University Press.

Falconer, C M 1898. Catalogue of a library, chiefly the writings of Andrew Lang. Dundee: Privately printed.

Fraser, R 1998. Victorian quest romance: Stevenson, Haggard, Kipling, Conan Doyle. Plymouth: Northcote House.

Gordon, G S 1928. Andrew Lang. London: Oxford University Press, H Milford.

Green, R L 1946. Andrew Lang: A critical biography with a short-title bibliography of the works of Andrew Lang. Leicester: Edmund Ward.

Greene, G 1969. Rider Haggard's secret. In Greene, G (ed.) 1969. Collected essays, 209-214. London: Bodley Head.

Haggard, E 1857. Myra: Or, the rose of the East. A tale of the Afghan War, in nine cantos. London: Longman \& Co.

Haggard, H R 1822. Cetywayo and his white neighbours. London: Trübner \& Co.

Haggard, H R 1926. The days of my life: An autobiography. London: Longman.

Haggard, L M R 1951. The cloak that I left: A biography of Henry Rider Haggard. London: Hodder and Stoughton.

Hall, R N \& Neal, W G 1902. The ancient ruins of Rhodesia: Monomotapae Imperium. London: Methuen.

Higgins, D S 1981. Rider Haggard: The great storyteller. London: Cassell.

Hilton, J L: Furor, Dementia, rabies: Social displacement, madness and religion in the Metamorphoses of Apuleius. In Bosman, P R (ed.) 2009. Mania: Madness in the ancient world. Acta Classica Supplement III, 84-105. Pretoria: The Classical Association of South Africa.

Hilton, J L 1998. An Ethiopian paradox: Heliodorus Aithiopika 4.8. In Hunter, R L (ed.) Studies in Heliodorus 1998:79-92. Cambridge: Cambridge Philological Society Supplementary Volume 21.

Huffman, T N 1987. Symbols in stone: Unravelling the mysteries of great Zimbabwe. Johannesburg: University of Witwatersrand Press.

Huffman, T N 2008. Mapungubwe: Ancient African civilisation on the Limpopo. Johannesburg: University of Witwatersrand Press.

Katz, W R 1987. Rider Haggard and the fiction of empire: A critical study of British imperial fiction. Cambridge: Cambridge University Press.

Kohne, E 2000. Gladiators and Caesars : The power of spectacle in Ancient Rome. Berkeley \& Los Angeles: University of California Press.

Krige, E J $1950^{2}$. The social system of the Zulus. Pietermaritzburg: Shuter \& Shooter.

Krige, E J \& Krige, J D 1943. The realm of a rain-queen. Cape Town: Juta. Kyle, D G 1998. Spectacles of death in Ancient Rome. London: Routledge. 
Lacroix, P \& Delzant, A (eds.) $1881^{3}$. Paul Jacques Raimond Bins De SaintVictor: Les Deux masques, tragédie-comédie. Paris.

Lambert, M 1990. Nomkhubulwana: The Zulu Demeter. Akroterion 35:46-59.

Lambert, M 2008: Nomkhubulwane: Reinventing a Zulu Goddess. In Carton, B, J Laband \& Sithole, J (eds.) 2008. Zulu identities: Being Zulu, past and present, 545-553. Pietermaritzburg: University of KwaZulu-Natal Press.

Lambert, M 2009. The madness of women: The Zulu Amandiki and Euripides'

Bacchae. In Bosman, P (ed.) 2009. Mania: Madness in the Greco-Roman World, 19-35. Pretoria: Acta Classica Supplementum III.

Lambert, M 2011. The Classics and South African identities. London: Duckworth. Lang, A 1882. Helen of Troy. London: George Bell \& Sons.

Lang, A 1885. Cupid, Psyche, and the "Sun-Frog". In Lang, A (ed.) 1885. Custom and myth, 64-86. London.

Lang, A 1884. Custom and myth. London: Longman.

Lang, A 1887. Myth, ritual and religion. 2 Vols. London: Longman.

Lang, A 1893. Homer and the epic. London: Longman.

Lang, A 1897. Modern mythology. London: Longmans, Green \& Co.

Lang, A 1906. Homer and his age. London: Longmans, Green \& Co.

Lang, A 1908. Homer and anthropology. In Marrett, R R (ed.) 1908. Anthropology and the classics: Six lectures delivered before the University of Oxford, 44-65. Oxford: The Clarendon Press.

Lang, A 1910. The world of Homer. London; New York [etc.]: Longmans, Green, \& Co.

Langstaff, E D S 1978. Andrew Lang. Boston: Twayne Publishers.

Lewis, C S 1982: The mythopoeic gift of Rider Haggard. Of this and other worlds, 128-132. London: Fount Paperbacks.

Low, G C-L 1996. White skins / Black masks: Representation and colonialism. London: Routledge.

McClure, J A 1994. Late imperial romance. London: Verso.

Miller, H 1952. The books in my life. London: Peter Owen.

Monsman, G C 2006. H. Rider Haggard on the imperial frontier: The political and literary contexts of his African romances. Greensboro: ELT Press.

Morris, W 1872. The earthly paradise: A poem. London: Ellis \& Green.

Müller, F M 1861. Lectures on the science of language. Series 1, 2. London.

Müller, F M 1867. Chips from a German workshop. 4 Vols. London, Oxford, New York.

Murray, S-A 1996. Tropes and trophies: The lost city "Discovered". Ariel 27.1: 149-176.

Pater, W 1934. Cupid and Psyche. In Pater, W (ed.) 1934. Marius the Epicurean, 36-52. London: Dent. 
Pocock, T 1993. Rider Haggard and the lost empire. London: Weidenfeld \& Nicolson.

Rider Haggard, H (trans. Viljoen, J). 1955. Rider Haggard: Kleopatra en Antonius. Johannesburg: Afrikaanse Pers.

Rosie, G 1937. Mapungubwe: Ancient Bantu civilization on the Limpopo. Manchester: The Institute.

Schlam, C C 1993. Cupid and Psyche: Folktale and literary narrative. GCN 5:63-74.

Shewan, A 1929. Andrew Lang's work for Homer. London: Oxford University Press, H Milford.

Siemens, L 1991. The critical reception of Sir Henry Rider Haggard: An annotated bibliography, 1882-1991. Greensboro: University of North Carolina.

Smith, W 1978. Search for a lost city. Reader's Digest 149-152.

Staffer, A M (ed.) 2006. Haggard, H R: She: A history of adventure. Ontario: Broadview Editions.

Stiebel, L 2001. Imagining Africa: Landscape in H Rider Haggard's African romances. Westport: Greenwood Press.

Stiebel, L 2009. On the trail of Rider Haggard. In Watson, N (ed.) 2009. Literary tourism and nineteenth-century culture. London: Palgrave Macmillan.

Symonds, J A 1875a. Helen of Troy. Cornhill Magazine 31.184:444-456.

Symonds, J A 1875b. Studies of the Greek poets. Vol. I.

Tangri, D 1990. Popular fiction and the Zimbabwe controversy. History in Africa 17: 293-304.

Tiley, S 2004. Mapungubwe: South Africa's crown jewels. Cape Town: Sunbird Publishing.

Tylor, E B 1871. Primitive culture: Researches into the development of mythology, philosophy, religion, art and custom. London: John Murray.

Vickery, J B 1973. The literary impact of the golden bough. Princeton: Princeton University Press.

Vinson, S 2008. They-who-must-be-obeyed: Arsake, Rhadopis, and Tabubue; Ihweret and Charikleia. Comparative Literature Studies 45.3: 289-315.

Vogelsberger, H A 1984. 'King Romance': Rider Haggard's achievement. Salzburg studies in English literature. Romantic reassessment; 92:3. Salzburg: Institut für Anglistik und Amerikanistik, Universität Salzburg.

Wessels, M 2010. Bushman letters: Interpreting / Xam narratives. Johannesburg: Witwatersrand University Press.

Whatmore, D E 1987. H Rider Haggard: A bibliography. London: Mansell.

Wilmot, A 1896. Monomotapa (Rhodesia): Its monuments and its history from the most ancient times to the present century with a preface by $H R$ Haggard. London: T F Unwin. 